Article

\title{
Narrating Animal Trauma in Bulgakov and Tolstoy
}

\author{
Anastassiya Andrianova
}

Department of English, North Dakota State University, Department 2320, P.O. Box 6050, Fargo, ND 58108-6050, USA; anastassiya.andriano@ndsu.edu

Academic Editor: Joela Jacobs

Received: 5 October 2016; Accepted: 8 November 2016; Published: 15 November 2016

\begin{abstract}
Following the recent "animal turn" in literary studies, which has inspired scholars to revisit traditional human-centered interpretations of texts narrated by animals, this article focuses on the convergence of animal studies and trauma theory. It offers new animal-centered close readings of Tolstoy's Strider and Bulgakov's Heart of a Dog, paying attention to animal pain rather than seeing it, and the text as a whole, as an allegory of human society. Like many other authors of literary fiction featuring animal narrators, Tolstoy and Bulgakov employ a kind of empathic ventriloquism to narrate animal pain, an important project which, however, given the status of both the animal and trauma outside human language, and thus susceptible to being distorted by it, produces inauthentic discourse (animal-like, rather than animal narration); therefore, these authors get closest to animal pain, not through sophisticated narration, but through the use of ellipses and onomatopoeia. Ultimately, any narratological difficulty with animal focalization is minor compared to the ethical imperative of anti-speciesist animal-standpoint criticism, and the goal is to reconceive the status of animals in literature so as to change their ontological place in the world, urging that this critical work and animal rights advocacy be continued in the classroom.
\end{abstract}

Keywords: animal narrators; animal studies; human-animal studies; speaking animals; Tolstoy; Bulgakov; trauma theory; Russian literature

But a full-grown horse or dog is beyond comparison a more rational, as well as a more conversable animal, than an infant of a day or a week or even a month, old. But suppose they were otherwise, what would it avail? The question is not, Can they reason? nor Can they talk? but, Can they suffer? Jeremy Bentham ([1], p. 7).

\section{Introduction}

Following the recent "animal turn" in literary studies, which has inspired scholars to revisit traditional human-centered interpretations of texts narrated by animals, such as Theodore Ziolkowski's catalogue of "talking dogs" [2], this article focuses on nonhuman animals as "a limit case for theories of difference, otherness, and power": the convergence of animal studies and trauma theory, both of which "raise questions about how one can give testimony to an experience that cannot be spoken or that may be distorted by speaking it" ([3], pp. 3-4). More specifically, it offers new animal-centered close readings of Leo Tolstoy's Strider: The Story of a Horse and Mikhail Bulgakov's Heart of a Dog, paying particular attention to animal pain rather than seeing it, and the text as a whole, as an allegory of human society. The present purpose is to reorient ostensibly animal-centered but actually human-centric interpretations so as to demonstrate what texts such as Strider and The Heart of a Dog reveal about animal narrators and animals in general, ultimately urging that this critical work and animal rights advocacy be continued in the classroom.

Tolstoy's Strider and Bulgakov's Heart of a Dog have been read as social and political commentaries, and even critics who have focused on the first-person animal narrators in these short novels, through philological, historical, political, and narratological lenses, have seen the animal experience as 
representative of human concerns [4-8]. With a few exceptions [9,10], critical readings tend to be human-centric even as the texts themselves center on the animal in pain. In Strider, the point of view shifts from omniscient narration to first-person testimony once the titular gelding begins to speak, revealing how his traumatic experiences (separation from his mother and castration) made him both self-aware and capable of narrating his life. In The Heart of a Dog, where a mongrel named Sharik is surgically transformed into a human being, the first-person canine perspective shifts to omniscient narration once Sharik becomes Comrade Sharikov (through the implantation of human testes and pituitary gland), but ultimately returns to Sharik once again, after this surgery has been reversed. Like many other authors of literary fiction featuring animal narrators, Tolstoy and Bulgakov employ a kind of empathic ventriloquism to narrate animal pain, an important project which, however, given the status of both the animal and trauma outside human language, and thus susceptible to being distorted by it, produces discourse that may not be authentic (animal-like, rather than animal narration) but is, nonetheless, our best shot at addressing the animal in pain.

If a lion could talk, and if we had the means to understand him, to paraphrase Ludwig Wittgenstein's famous proposition, is a much debated question in animal studies [11]. ${ }^{1}$ Kari Weil has written on the ways primate research, conducted by Sue Savage-Rumbaugh at the Great Ape Trust in Iowa, brings us closer to interspecies communication, but she also warns against attempts "to teach apes to sign in order to have them tell humans what they want" ([3], pp. 3, 5-6). Added to animals' historically inferior ontological status and perceived voicelessness is the narratological problem associated with focalizing an animal's perspective. As William Nelles points out, "first-person or homodiegetic examples ... pose the problem of assigning human language to animals, who by definition cannot speak" [12]. Gerard Genette does, however, suggest the possibility of animal focalization by leaving the term 'personnages' somewhat ambiguous in a footnote to the definition of the "homodiegetic" type of narrative, where "the narrator is present as a character in the story he tells": "This term [personnages] is used here for lack of a more neutral or more extensive term which would not unduly connote, as this one does, the 'humanness' of the narrative agent, even though in fiction nothing prevents us from entrusting that role to an animal ... or indeed to an 'inanimate' object" ([13], pp. 244-45, note 74). While many narratologists have understood this as a dismissal of animal narration, the large number of fictional texts with animal focalizers justifies their study [12]. Such objections to animal narration and the difficulties involved are, furthermore, minor compared to the ethical imperative of forging anti-speciesist approaches to reading and treating animals.

While heeding the animal in pain, my goal is not merely to reinforce the violence already inflicted by the critics' scalpels. Arguing against aestheticizing violence and cruelty to animals, Josephine Donovan criticizes interpretations in which the "circumstantial realities of the animals themselves are largely ignored so that the perceived pathos of their condition may be used to illustrate the mental state or moral condition of the humans. "In short," she claims, "the moral reality of the animals' suffering is overridden in the interest of creating an aesthetic effect" ([14], p. 206). This is especially evident in analyses of metaphors and other figurative language, which "may thus be seen as a form of parasitical exploitation or metaphysical cannibalism of one entity (the vehicle) for the benefit of the other (the tenor)" ([14], p. 207). In the following pages, I will explore, in more depth, "the unrepresentable" ([15], p. 573) discourse of animal trauma and the empathic ventriloquism invented by human authors to vocalize, and focalize, nonhuman animal perspectives. To demonstrate that it is, indeed, possible to avoid aestheticizing animal violence and cannibalizing their experience for human gain, I engage in what Donovan calls "animal-standpoint criticism." This approach is grounded

1 Constantine Sandis sets out to criticize (mis)readings from the animal perspective which ignore the philosophical context of Wittgenstein's remark, "Wenn ein Löwe sprechen könnte, wir könnten ihn nicht verstehn" ("If a lion could talk, we could not understand him"); however, he also notes that along with "Elizabeth Anscombe's commonly accepted translation of 'könnten...nicht' as 'could not', which implies it is impossible, ... there are actually three different [interpretive] translations" that leave the possibility of animal communication open ([11], pp. 1-3). 
in the view that "animals are seats of consciousness-subjects, not objects; that they are individuals with stories/biographies of their own, not undifferentiated masses; that they dislike pain, enjoy pleasure; that they want to live and thrive; that in short they have identifiable desires and needs, many of which we human animals share with them" ([14], p. 204).

\section{The Elephant in the Room}

By interpreting animal pain allegorically, literary scholars may not have actively promoted animal suffering, but they have not helped to alleviate it either. Buttressed by documented findings in ethology and animal science, animal narratology can make a doubly powerful claim for empathy. That animals experience pain has, indeed, been proven empirically. One such experiment is Francis C. Colpaert's study on animals and pain medication in the 1980s. Colpaert injected rats with bacteria that induce arthritis and offered them a choice of bad-tasting analgesic and sweet, sugary-tasting liquid; these arthritic rats, the experiment indicated, were choosing the painkiller not for its taste [16]. The structures of their neurological systems provide more evidence for animal pain as well as consciousness. The brains of mammals have "a neocortex, the cauliflower-like portion of the brain that features ridges and in-foldings," which makes them capable of consciously experiencing pain ([17], pp. 74-75). In Animal Liberation, Peter Singer argues that other species have "[n]early all the external signs that lead us to infer pain in other humans," including such behaviors as "writhing, facial contortions, moaning, yelping or other forms of calling, attempts to avoid the source of pain, [and] appearance of fear at the prospect of its repetition" ([1], p. 11). Similarities in nervous systems along with physiological responses (variations in blood pressure, perspiration, and heart rate) yield further evidence that animals can feel pain, and although humans possess a more developed cerebral cortex, animals' diencephalon, significantly developed in mammals and birds, enables them to experience impulses, emotions, and feelings. Animals' capacity for pain serves, moreover, the same evolutionary function as humans': to prevent injury thereby also enhancing a species' chances at survival, all of which leads Singer to conclude that animals must also have a similar subjective experience of pain ([1], p. 11).

Additionally, recent research has shown that contrary to "corticocentrism," or the speciesist claim that an organism must have a neocortex to "possess a humanlike capacity for pain," even fish can exhibit the presence of consciousness due to the medial pallium, which performs a similar function to that of the human amygdala and helps drive memory, decision making, and emotions, including responses to various stimuli from stress to joy ([17], pp. 74-75, 89). Studies of largemouth bass populations show they become hook-shy after being hooked and released, indicating that repeat-hooking is motivated by hunger and should not be taken as evidence of an absence of pain ([17], p. 76). Studies of rainbow trout show, similarly, that they "are equipped to respond to different types of potentially painful events: mechanical injury (like cutting or stabbing), burning, and chemical damage (from acid)," and that their negative reactions were reduced by the use of morphine ([17], pp. 78-79).

Prior to considering whether the animal's suffering is posited merely for "an aesthetic effect" ([14], p. 206), or as a vehicle for speciesist, human-centric critique, we must acknowledge the presence of not one but two elephants in the room: that animals are capable of consciously experiencing pain, and that pain is utterly subjective, notoriously impossible to locate, and ultimately unnarratable and unrepresentable. Whereas in the case of human trauma, as Cathy Caruth argues, what is initially incomprehensible can potentially be narrated belatedly, with the delay allowing "history to arise where immediate understanding may not" ([18], p. 11, original emphasis), in the case of animals, there may not be a belated history, at least not one we can understand given the limitations of human language. As Weil has shown, both animal studies and trauma studies draw attention to "the violence done to animals and their habitats" and to "the difficulty of assessing how animals experience that violence," and hence "raise questions about how one can give testimony to an experience that cannot be spoken or that may be distorted by speaking it" ([3], p. 4). In the case of prey animals especially, expressing suffering may be precarious. Prey animals, such as horses, mask their pain more than predators 
and can be "incredibly uncomplaining"; those that do show pain, through "contorted positions" and moaning, "do this only when they're alone" ([19], p. 181). ${ }^{2}$ As we will see shortly, this makes Strider's autobiographical account-given to several other horses and indirectly to many more human readers-at once less plausible and more poignant.

\section{What Tolstoy's Gelding Can Tell Us about Animal Trauma}

Perhaps the most striking representation of "the unrepresentable" is the ellipsis in the middle of Leo Tolstoy's short novel Strider: The Story of a Horse (Kholstomer, 1886), at the moment when the eponymous stallion is transformed into a "piebald gelding" ([20], pp. 79, 83). Over the course of five nights, the aging Strider tells the other horses in the moonlit paddock about his unfortunate coloration, abandonment by his mother, unrequited first love, and subsequent castration:

Then the general threatened to thrash everyone and said that I must be castrated. The head keeper promised to carry out his orders. Then they all quieted down and left. I didn't understand a thing, but I could see that they were planning to do something to me.

$\cdots$

'The day after that I stopped neighing for ever and I became what I am now. In my eyes the whole world had changed. Nothing held any joy for me, I withdrew into myself and abandoned myself to reflection. At first everything revolted me. I even stopped drinking, eating and walking, and playing with my companions was out of the question. Sometimes I had the urge to jib, canter and neigh, but immediately I would ask myself the terrifying questions: why? for what? And my last ounce of strength drained away ([20], p. 84, original emphasis).

In the original Russian, the ellipsis is even more pronounced, receiving two full lines of dots ([21], p. 111):

Signaling a moment of emotional intensity, a double-line ellipsis occurs only one other time, at the start of Chapter X, which switches perspectives (from first-person to omniscient) to narrate the visit of Strider's old owner, Serpukhovskoi, whom the gelding recognizes immediately, but who, having abandoned him in the past, now also tragically fails to reciprocate ([21], p. 123). This use of punctuation seems deliberate; a single-line ellipsis is used three times in two earlier chapters to demarcate animal speech, or a different section within animal speech: right before the chapter in which Strider begins to speak, right before the actual moment of his speaking, and right before he begins his autobiography proper after introducing himself ([21], pp. 106-7).

This unnarrated, and arguably unnarratable, violence makes Strider both inquisitive (he "abandoned [him]self to reflection") and remarkably astute, as he starts to question the notion of private property, especially when applied by humans to (their) animals: "I understood full well what he said about flogging and Christianity, but I didn't have the least idea what the words mine, my foal meant ... I found it impossible to understand how and why I could be called a man's property. The words my horse, referring to me, a living creature, struck me as strange, just as if someone had said my earth, my air, my water" ([20], p. 86, original emphasis). The Russian formalist Viktor Shklovsky gave Tolstoy's story as an example of defamiliarization (ostranenie) in his seminal essay

2 At one point Grandin describes the castration of bulls by a veterinarian using "a rubber band procedure, wrapping a tight band around the bull's testicles and leaving it there for several days," a procedure considered "less traumatic than surgery, although there are individual differences in how cattle react to it": "Some bulls are perfectly normal, while others repeatedly stamp their feet. I interpret foot stamping as a sign of discomfort but not overwhelming pain. A few bulls, though, act as if they're in agony. They lie down on the ground in strange, contorted positions and they moan-but they do this only when they're alone" ([19], p. 181). 
"Art as Technique" (1917), noting that "it is the horse's point of view (rather than a person's) that makes the content of the story seem unfamiliar" ([6], p. 21); this technique, moreover, in the words of Hugh McLean, "became a favourite, almost patented [one] of Tolstoy's art" and so "compels the reader to see human beings and their behaviour in new ways" ([20], p. xviii). Yet by focusing on the use of defamiliarization, critics of Strider have inevitably downplayed the literality of the animal's pain. A telling example of Soviet-era criticism can be found in E. Zhezlova's note on Kholstomer in the 1958 collected works edition, where there is not a single reference to the narrator's being a horse; rather, he is a "creature [sushchestvo] close to nature" (which could apply to humans and nonhumans alike), and "the story is about his 'fate' and 'thoughts"' (placed in quotation marks presumably to indicate their uncertain status), which also exposes "the mercenary world of property owners" and poses "the most important social questions" ([21], pp. 489-90, my translation). ${ }^{3}$ The brief description humanizes the gelding by erasing his animal difference.

By reading Tolstoy's story from the perspective of animal studies, on the other hand, we notice that there is more here than "a horse's perspective on human life", or a satire on "all the folly, decay, moral emptiness, and socioeconomic parasitism of the representatives of the ruling class in imperial Russia," as Strider's Soviet critics insisted ([8], p. 546). The ellipsis in the text marks the point of intersection of animal studies and a theory of trauma as both "problematize representation and attempt to define its limits-discourses of the sublime, the sacred, the apocalyptic, and the other in all its guises" ([15], p. 573). We come to see more than the somewhat arbitrary problem that animal focalization poses for narratology, being, in Genette's typology, a type of first-person or homodiegetic focalization, which thus "assign[s] human language to animals, who by definition cannot speak" [12]. We arrive, in effect, at the animal's inability to narrate her pain, as animal discourse, like that of trauma, is also the "discourse of the unrepresentable, of the event or object that destabilizes language and demands a vocabulary and syntax in some sense incommensurable with what went before" ([15], p. 573).

Shifting the conversation toward "the themes of sex, love, and motherhood in this story about a castrated horse," along with the implications of thwarted sexual desire, Ronald D. LeBlanc offers an insightful and much needed analysis of that which is elided in the text and has been ignored by critics who read the story as an allegory about the landed gentry [8,22]; he sees in the gelding's selfless service to others following his castration "the expression of an ascetic desire on the part of the author to be unburdened of what he saw as the affliction of sexual lust and thus to be freed to pursue a more spiritual, less carnal existence on earth, a position that Tolstoi would later promulgate as part of his championing of a noncarnal, Christian brand of love" ([8], pp. 546-47). LeBlanc's treatment of "the piebald gelding" is more sympathetic than that of Aleksandr Etkind, for example, who sees the castration as ultimately beneficial for the horse and "an appropriate cure" for the "ailment" that is lust, because "if Kholstomer had not been castrated, it is unlikely he would have come to the moral insight that he does" ([8], pp. 556-57). LeBlanc's reading is still largely human-centered, positing that Strider be seen, at least in part, as Tolstoy's own (human) autobiography.

Andrea Rossing McDowell takes an animal studies approach which similarly draws on Tolstoy's biography, linking the author's vegetarianism and pacifism with his other, more frequently explored principles, including "his opposition to serfdom, the role of women in society, the devolution of sexual mores, and the destruction of rural life through modernization" ([9], p. 1). She insists that "The First Step" (1891), Tolstoy's famous essay which "aligns the consumption of meat with moral vices," is especially revealing of his attitude toward animals, contrary to other Tolstoy scholars who continue to "minimize the connection between his vegetarianism and his compassion for the animal world" ([9], p. 2). By foregrounding the animal's trauma, both the physical pain of castration and the accompanying emotions of abandonment and alienation due to his piebald coloration and gelding

3 Quotations from Russian are transliterated according to a simplified version of the Library of Congress' ALA-LC Romanization Tables, omitting ligatures. 
status, McDowell turns the conversation toward the animal: "This extreme personalization of the animal tragedy makes Tolstoy's tale doubly successful as an allegory of human society and a literal injunction to treat non-human species with greater consideration" ([9], p. 10). She concludes, however, not unlike Etkind, by recognizing the paradox of Strider's castration, or "'ideal' celibacy": "The initial trauma represents an act of power and abomination that ravages the victim's sense of self and precludes immortality through progeny; conversely, it frees the sufferer from 'animal' desires of the flesh, thereby encouraging more virtuous contemplations" ([9], p. 11). In this respect, the story supports Tolstoy's own grappling with celibacy and Christianity ([8], p. 557) and perhaps explains why, having started the story in the 1860s, he would not finish it for another 20 years.

There is, admittedly, some value to biographical criticism. In an often-quoted anecdote reported by Tolstoy's fellow writer Ivan Turgenev, the latter recalls seeing Tolstoy "by a bony, mangy old nag, stroking its back and whispering gently into its ear, while the horse listened with evident interest" ([10], pp. 45-46): "I was absolutely spellbound by what I heard," Turgenev reports. "Not only did he himself enter into the inner condition of this unfortunate creature, but he brought me into it as well. I couldn't restrain myself and said to him: 'Listen, Lev Nikolaevich, you really must have been a horse once yourself.' One could not find a better rendering of the inner condition of a horse" ([8], p. 545). Moreover, the "description of Strider's death may derive from an actual visit Tolstoy paid to a slaughterhouse at about this time" ([10], p. 44). But this also brings us to a critical impasse: animal focalization, rendered by any human, even one possibly reincarnated as a horse, is still the product of human imagination and empathy, reported through human language "giv[ing] testimony to an experience that cannot be spoken" and likely "distort[ing it] by speaking" ([3], p. 4). I would argue, however, that the creative impulse to give voice to the so-called dumb beasts, by making them narrators of their own literary fiction, is still less damaging than literary criticism's tradition of allegorizing their experiences_thus, in the words of Philip Armstrong, "reduc[ing] the animal to a blank screen for the projection of human meaning" ([14], p. 203).

\section{Rescuing Bulgakov's Mongrel from Under the Critic's Scalpel}

Mikhail Bulgakov's Heart of a Dog (Sobach'e Serdtse, 1925) is the story of a radical transplant, Professor Preobrazhensky's unprecedented rejuvenation experiment which transforms a sympathetic mongrel into a despicable "new Soviet man," who drinks, spits, curses, and plays the balalaika. This "wonderfully angry novel," in the words of Andrey Kurkov, makes us wonder about the relationship between Bulgakov and Stalin ([23], p. ix). Employing "comic absurdity" to allegorize the Bolshevik Revolution, the story's "fantastic realism" gave it appeal as political satire while also allowing Bulgakov to avoid prosecution, though not censorship, by the ruling Proletariat it criticized. Although initially accepted for publication, the manuscript was confiscated in 1926 and published in Germany only in 1968; in the Soviet Union, it did not appear in print until 1987 ([24], p. 491, note 1).

Since the novel's publication, Bulgakov's dog has received wide critical attention, linking the Professor's scalpel with larger social transformation movements of the 1920s, and rejuvenation with revolution. Brett A. Berliner, whose essay catalogs relevant literature on rejuvenation, claims the surgery is "a symbolic means to address the central issue in the Soviet Union: the wholesale transformation of society and people," about which Bulgakov "was distinctly pessimistic" ([4], p. 109). According to Michael Glenny, "The 'dog' of the story is the Russian people, brutalized and exploited for centuries - treated, in fact, like animals instead of human beings," and the message is that "the Russian intelligentsia, which made the Revolution, is henceforth doomed to live with-and eventually to be ruled by — the crude, unstable and potentially brutal race of hominids-homo sovieticus—which it has called into being" ([23], pp. xiii-xiv). In her 1984 biography of Bulgakov, Ellendea Proffer similarly sees the story as an allegory of the revolutionary transformation of society and a cautionary tale about 
science meddling with nature ([5], pp. 123-33). ${ }^{4}$ LeBlanc analyzes the use of food imagery and eating metaphors in Bulgakov's satire to make a larger claim about the author's political project: "What the people of Russia need is a moral, spiritual, and cultural leadership that, in addition to providing them literally with their daily bread, is capable of feeding them spiritual food as well, thus nurturing and preserving within them lasting cultural values" ([25], p. 67). The value of political readings cannot be overstated, nor can that of animal focalizers who serve as powerful spokespersons for otherwise unpublishable critique. Yet, such readings tend to be concerned less with the wellbeing of the individual mongrel than with that of the suffering, disenfranchised "people of Russia" whom he comes to represent.

Some have criticized political interpretations for being reductive and turning multifaceted characters into allegorical symbols. The Professor, Diana L. Burgin maintains, is one such "complex literary character-a potentially tragic hero ... who serves as an autobiographical spokesman for [Bulgakov's] political and social satire and as a tragic, Romantic hero in the Frankenstein tradition" ([26], p. 494). The subtitle, not included in Glenny's translation, is "A Monstrous Story" (Chudovishchnaia istoriia), which clearly alludes to Frankenstein, as does the Professor's surname, Preobrazhensky, which connotes transformative, mystical power. Others have offered valuable analyses of Bulgakov's use of language. Building on Katerina Clark's "promethean linguistics," Eric Laursen reads The Heart of a Dog in the context of the 1920s belief in the power of language as "the ultimate vehicle for the kind of transformation sought by revolution"; as such, the novel represents the post-revolutionary "struggle for cultured speech" through pure, "civilizing" language, "an integral component of Bolshevik campaigns to promote 'culturedness' in 1923-1924" ([24], pp. 492-93). Susanne Fusso similarly homes in on Bulgakov's "skeptic[ism] about the possibility of instant, irreversible metamorphosis through the magical power of language" and argues that in the novel's materialistic universe, "verbal transformations remain figures of speech and physical transformations are difficult, slow, and incomplete" ([7], pp. 387, 393). Interestingly, Sharik's transformation into a "new Soviet man" evokes a series of Russian figurative expressions involving the word dog (sobaka), such as "a dog's happiness" (sobach'e schast'e, the original title of the work), "a dog's life" (sobach'ia zhizn'), and an idiom attested by Vladimir Dal', the great Russian lexicographer: "Don't beat the dog, for even she used to be human, having been transformed into a dog due to gluttony" (Ne bei sobaki, i ona byla chelovekom, obrashchena v psa za prozhorlivost') ([7], p. 391, my translation). The preponderance of canine figures, not to mention the Aesopian idiom which straddles the human/animal divide, sheds light onto why Bulgakov may have chosen a dog as his narrator as well as the subject of the experiment. Even in these alternative approaches, however, stressing that Sharik is more human than the human Comrade Sharikov whose organs he inherits, the focus is on humanity at the expense of the animal.

"Imagine your dog walking by the mirror in the hallway and screeching to a halt the way we do when something unusual catches our eye," primatologist Frans de Waal muses in The Inner Ape. "We would be shocked! The dog cocks his head and checks out his image in the mirror, shaking his head to unfold a folded ear or removing a twig stuck in his fur. Dogs never do this, but it's exactly the sort of attention apes pay to themselves" ([27], p. 184). Waal's point here is to dispel myths about apes and bridge the divide between humans and other primates; it is not (expressly) to dismiss dogs' reflections or, for that matter, their power to reflect. Curiously, we find the mongrel in Bulgakov's short novel doing just that, reflecting on his dogness while checking out his reflection in the mirror:

I am handsome. Perhaps I'm really a dog prince, living incognito, mused the dog as he watched the shaggy, coffee-coloured dog with the smug expression strolling about in the

4 It is worth noting that Bulgakov was trained as a doctor and had practiced medicine before turning to literature. While from his portrayal of Sharik, the pet, we might infer the novelist's benevolent and empathetic attitude, in the chapter describing the operation, informed no doubt by his own practical experience, Bulgakov, in Susanne Fusso's words, "spares no detail of spurting blood or oozing tissue" as he "emphasizes the intense physicality of surgery" ([7], p. 391). The latter, arguably, tells us more about his attitude toward the brutality of science-and the Bolshevik revolution-than toward animals. 
mirrored distance. I wouldn't be surprised if my grandmother didn't have an affair with a labrador. Now that I look at my muzzle, I see there's a white patch on it. I wonder how it got there. Philip Philipovich is a man of great taste- -he wouldn't just pick up any stray mongrel ([23], p. 41).

The dog's sophisticated narration, one of the novel's satirical (and absurd?) elements, places him in the company of other "talking dogs" in Ziolkowski's famous "literary cynology," alongside Miguel de Cervantes" "The Colloquy of the Dogs" and Nikolai Gogol's "The Diary of a Madman" ([2], pp. 95, 115). But is Waal right, is this not "the sort of attention" dogs pay to themselves but, rather, behavior more suitable to Sharik's primate counterpart?

Helena Goscilo argues that the first-person dog narration is used to produce a comic effect, make the reader like the dog, and elevate Preobrazhensky ([28], p. 286). Yvonne Howell, who reads The Heart of a Dog in the context of the Russian eugenics movement, suggests that comic absurdity is created by mixing nonhuman narration with human knowledge: "When Bulgakov adopts the dog's perspective for extended passages of the narration, he does not limit himself to what the dog might know. Instead, for comic effect, he endows his canine character with rather sophisticated medical knowledge ... , sharp class consciousness ... , and surprising worldliness" ([29], p. 551). Another critic charges that the dog's "seemingly first-person narrative" is, in fact, "contaminated by the voice of an omniscient third-person narrator" ([7], p. 389). Although embedded in Glenny's English translation without any distinguishing punctuation, this mirror passage is enclosed in quotation marks in the original Russian, thereby marking off the dog's interiority ([23], p. 539). Glenny's choice to omit quotations, on the other hand, effectively extends the canine perspective beyond that which Sharik narrates and into the surrounding third-person omniscient narration, as in the description of the radiator preceding this passage, which is given from the dog's perspective (the dog's eyes being level with the radiator), even if the dog is not the homodiegetic focalizer: "Clearly the country was not yet in a total state of ruin. In spite of it the great accordion-shaped radiators under the windows filled with heat twice a day and warmth flowed in waves through the whole apartment. The dog had obviously drawn the winning ticket in the dogs' lottery" ([23], p. 41). It is this contamination of narrative discourse that leads Fusso to conclude that Bulgakov's is "a kind of ventriloquism" and "a dog-like narration," rather than "a dog's narration":

Even S[h]arik's first-person narration, however, is invaded by bits of information that could be known only to the omniscient narrator, thus disturbing the illusion that the dog is speaking. S[h]arik lets fall certain facts that he could not possibly know at this point ... The inevitable conclusion is that the opening narration is actually in one voice, but a voice that shifts between an objective presentation and an imitation of a dog's-eye view-a kind of ventriloquism. Bulgakov lays bare the convention of representing a character's inner life. The narrator indeed transforms himself into a dog, but it is an imperfect transformation. Gaps and incongruities are left in order to signal that this transformation too remains on the level of figurative language. This is not a dog's narration but a dog-like narration ([7], pp. 389-90).

Another example of this mixed or "contaminated" voice is found just as the dog crosses the threshold into Preobrazhensky's apartment, which serves also as the Professor's clinic and operating room. This threshold is marked by a plaque that bears the Professor's title, including the letter $\Phi$ the street-smart Russian dog, who taught himself to read, cannot decipher, as this letter is used predominantly in non-Slavic words: "P-R-O- 'Pro ... ', but after that there was a funny tall thing with a cross bar which he did not know. Surely he's not a proletarian? Thought Sharik with amazement ... He can't be. He lifted up his nose, sniffed the fur coat, and said firmly to himself: No, this doesn't smell proletarian" ([23], p. 13). The question is set off by quotation marks in the original Russian, which, again, emphasizes the dog's direct speech, yet in both cases the point of view is clearly canine even though it is not focalized through the first person ([30], p. 524). This point of 
view is, at the same time, "contaminated" insofar as Sharik is able to demonstrate a more-than-canine awareness of class difference between professors and proletarians, despite their similarly sounding names; through his physiological transformation, as Sharikov, he also loses his alleged ties to aristocracy (the aforementioned labrador romance) and joins the very class he despises. Along with class consciousness, Laursen notes that the dog's control over the written word and his ability to analyze the world are strong outside the Professor's apartment, but get leashed as soon as he is collared: inside the apartment, the dog's "control of narration is completely relinquished. He is not only given the new name Sharik but is also permanently renamed at the narrative level, as the ' $\mathrm{I}$ ' becomes a 'he'" ([24], p. 497). "With his collar, the dog gains status but forfeits a true understanding of the world around him ... He is sedated, his point of view vanishes, and we learn that the dog has been chosen not as a noble pet but as a disposable scientific subject" ([24], p. 498).

The kind of empathic ventriloquism that is more valuable to animal-standpoint criticism is to be found, therefore, not in the "contaminated" or "dog-like narration," and not even in the sophisticated "I" narrative, but in the opening line of the text: the onomatopoeia which approximates sounds actually made by a dog: "Ooow-ow-ooow-owow!" — "U-u-u-u-u-u-gu-gu-gugu-uu!" in the original ([23], p. 3; [30], p. 519). This is followed by a verbal expression of pain:

Oh, look at me, I'm dying. There's a snowstorm moaning a requiem for me in this doorway and I'm howling with it. I'm finished. Some bastard in a dirty white cap-the cook in the office canteen at the National Economic Council—spilled some boiling water and scalded my left side. Filthy swine-and a proletarian, too. Christ, it hurts! That boiling water scalded me right through to the bone. I can howl and howl, but what's the use? ([23], p. 3).

Shorter instances of onomatopoeia meant to phonetically imitate howling-technically also an onomatopoeic word (the verb is vyt' in Russian, and the noun form, voi) - can be found in the subsequent narration, as well, often preceded or followed by ellipses in both the original and the translation: " ... Oow-owowow ..."; " ... grrr ... bow-wow ..." " "Oowow, owow ..." ([23], pp. 3, 7; [30], pp. 519, 521). Arguably, these strings of syllables which resemble dog noises get us closer to Sharik's interiority than the accompanying sophisticated homodiegetic focalization. Whether dogs, or animals in general, know death is debatable, though the ethical treatment of animals evolves precisely from our shared mortality as well as bodily vulnerability, a view supported by Weil, Jacques Derrida, Donna Haraway, and Cora Diamond [31]. That animals feel pain is harder to deny, which takes us back to the 'unrepresentability' of trauma.

Animal sounds are among the most familiar onomatopoeic words. ${ }^{5}$ Of all the diverse sounds made by dogs, it is barking that "come[s] closest to speech sounds," as it is produced analogously "by vibrations in the vocal folds and air flowing along folds and through the mouth cavity." This structural similarity may be responsible for the multiple onomatopoeic renditions of dog barking using (human) phonemes: woofs, rufs, arfs, and bow-wows ([33], pp. 105-6). Recent research into dog barking has helped scientists distinguish between different barks, with lower sounds communicating a threat and higher-frequency sounds-an entreaty, request, or submissive gesture ([33], pp. 107-8). Added to this is the dog's body language (rumps, heads, ears, legs, and tails), which is equally communicative, including, for example, urination used for marking ([33], pp. 112, 116). There seems to be little consensus in discussions of onomatopoeia on what to call the second term in the relation between the sound of a word and what it signifies, these being "variously referred to as sounds, sense, referent, and what is denoted"; the function of the first term, too, is variously described as "imitates, echoes, reflects, resembles, corresponds to, sounds like, expresses, reinforces, and has a natural or direct relation with" ([34], p. 555). In such definitions, the etymological meaning of the term, from

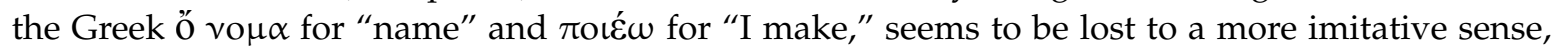

5 For more on the onomatopoeic origins of language, such as Max Müller's now discredited "bow-wow" theory which traces the origins of language to the imitation of natural sounds, see ([32], p. 117). 
contrary to what we find, for instance, in Quintilian's Institutio Oratoria, "namely, the creation of a word ex novo" ([34], p. 556). When rendering animal noises, both meanings of onomatopoeia appear to be correct, for we are creating new or rearranging existent phonemes to resemble and sound like the animal, though whether, how, and to what exactly these correspond may never be ascertained. Still, as with ellipses in Tolstoy's Strider, the phonetic echoes and fragmentary verbalizations, not the humanizing social critique of the National Economic Council, bring us closer to the experience of animal pain qua animal.

One might argue that relegating animal "speech" to onomatopoeia is an essentially logocentric move, one which privileges human-centric semiotics and reinforces the hierarchy between human language and animal vocalization. Yet, it is also a reasonably anthropomorphic gesture that recognizes the capacity of nonhuman animals to communicate while respecting their difference. In his discussion of the use of onomatopoeia in Lucretius' De rerum natura, Benjamin E. Stevens notes that "[a]nimal vocalizations are indeed not words because animals are physiologically inarticulate, but also ... because, semiotically, animals cannot denote or name"; in other words, animals have neither the proper physiological equipment to form words, nor the semiotic ability to use symbols, necessary for voluntary signification using arbitrary signs ([35], p. 544, note 40). Whereas animal vocalizations of emotions, "in direct response to an immediate stimulus," are "indexical and symptomatic" (based on contiguity and proximity), human responses are intentional, symbolic, capable of denoting things. Despite these differences, "the two kinds of signification ... are nonetheless equally 'natural,' in an Epicurean sense, to the inherent semiotic abilities of their respective groups: humans signify symbolically, animals only indexically or symptomatically" ([35], p. 530). Haraway has convincingly argued that the traditional line between human and nonhuman worlds has now been "thoroughly breached" given our discovery of similarities in "language, tool use, social behaviour, [and] mental events" ([36], pp. 151-52). To acknowledge that both have semiotic abilities, but that these abilities are different, is a way to bring animal difference into semiotics. Sharik's onomatopoeia can be considered seriously, as an expression of a painful emotion, even if automatic and immediate. To judge the talking dog on its human speech, on the contrary, is to erase this animal difference. The technique of empathic ventriloquism (etymologically, from the Latin 'venter', belly and 'loqui', speak) seems at its best, then, when the narrator does not speak but bow-wows, releases the animal sounds straight from his belly, his physical being. If animal focalization is inauthentic, and animal trauma ultimately unnarratable, onomatopoeia is, perhaps, the next best thing.

\section{Conclusions: Teaching Animals, a Pedagogical Imperative}

In her book on decoding animal behavior, Temple Grandin relates a famous story told by New Zealand animal psychologist and ethologist Ron Kilgour about transporting a pet lion on an airplane. "Someone thought the lion might like to have a pillow for the trip, the same way people do, so they gave him one, and the lion ate it and died. The point was: don't be anthropomorphic. It's dangerous to the animal. But when I read this story," Grandin writes, "I said to myself, 'Well, no, he doesn't want a pillow, he wants something soft of lie on, like leaves and grass.' I wasn't looking at the lion as a person, but as a lion" ([19], p. 15). Animal narration in Strider and The Heart of a Dog is not anthropocentric in any objectionable way, but their empathic ventriloquism is anthropomorphic because these authors' human worldviews inadvertently condition their understanding and representation of the animal's Umwelt (the sensory world as it is experienced by a particular animal, as ethologist Jakob von Uexküll has called it) ([3], p. 8; [17], p. 25; [37], p. 7).

Even if Tolstoy's and Bulgakov's animal narrators are empirically unprovable feats of ventriloquism, and animal consciousness is inaccessible given the limitations of human language and imagination, we should not take that as an excuse not to care. In a recent book provocatively titled Being a Beast, Charles Foster writes: "The universe I occupy is a creature of my head ... But we need to keep trying. If we give up with humans, we're wretched misanthropes. If we give up with the natural world we're wretched bypass builders or badger baiters or self-referential urbanites" ([38], pp. 14-15). 
After recounting his attempts to see and feel like an animal, Foster adds, "our [human] capacity for vicariousness is infinite. Empathize enough with a swift and you'll either become one or (which may be the same thing) you'll be able to rejoice so much with the screeching race around the church tower that you won't mind not being one yourself" ([38], p. 216). Similarly, when talking about dogs, Alexandra Horowitz suggests that it is not enough for humans to imagine or think about being "excellent smellers," smell being a canine specialty; this exercise must be "paired with an understanding of how profound the difference in umwelt is between us and another animal." We can achieve this "by 'acting into' the umwelt of another animal, trying to embody the animal-mindful of the constraints our sensory system places on our ability to truly do so" ([33], p. 23). Whether Tolstoy really was a horse in a former life, he and Bulgakov bring their readers one step closer to the animal's 'unrepresentable' Umwelt.

By way of conclusion, I urge that we include animals, such as Tolstoy's Strider and Bulgakov's Sharik, in university curricula in order to raise questions of inequality and social justice associated with animal welfare and also to help students develop empathy for animals, both human and nonhuman. The "animal question," as Weil has argued, is, after all, "an extension of those debates over identity and difference that have embroiled academic theory over the past quarter century," and by attempting to bring into theory nonhuman animals, whose voices cannot be (readily) integrated and who cannot-without much more theoretical work and a fundamental reconfiguration of poststructuralism's insistence on language-be transformed from objects into subjects, we can see that they are, in fact, "a limit case for theories of difference, otherness, and power" ([3], p. 3). "Like trauma studies," Weil explains, "animal studies thus stretches to the limit questions of language, of epistemology, and of ethics that have been raised in various ways by women's studies or postcolonial studies: how to understand and give voice to others or to experiences that seem impervious to our means of understanding; how to attend to difference without appropriating or distorting it; how to hear and acknowledge what it may not be possible to say" ([3], p. 4). When questioned as to the whereabouts of Comrade Sharikov, and facing accusations of murdering Sharik's human incarnation, the Professor broaches the difficult ontological distinction which drives the novel's plot: "'Because he talked?' asked Philip Philipovich. 'That doesn't mean he was a man'" ([23], p. 125). Ironically, it is precisely through speech, his effective use of homodiegetic focalization, that Bulgakov's dog is humanized, though the canine perspective is simulated better through onomatopoeic animal vocalization than sophisticated human language. The ellipsis that marks Strider's transition from a stallion to a gelding serves a similar function: it gives a voice to that which is 'unrepresentable.'

At the end of the day, "The question is not, Can [a full-grown horse and dog] reason? nor Can they talk? but, Can they suffer?" as Jeremy Bentham reminds us in the passage which opens with a hope that has yet to be realized: "The day may come when the rest of the animal creation may acquire those rights which never could have been withholden from them but by the hand of tyranny" ([1], pp. 7, 203-4). It is their status as the ultimate other that makes teaching animals a pedagogical imperative, one meant to challenge readers to exercise their analytical skills more rigorously than when deciphering the motives of human characters which may be only partially elucidated in literary fiction, the reading of which has recently been linked with developing empathy [39]. This is also what Elizabeth Costello, the titular character of J. M. Coetzee's 2003 novel, calls "sympathy," our ability to "think ourselves into the being of another," a faculty that is mastered by novelists, who have to think themselves into the existence of fictional characters, but can be practiced by anyone and extended to "any being with whom [we] share the substrate of life" ([40], p. 80). Teaching animals can invite literary scholars and students to interrogate the human/nonhuman boundary and to recognize the animal traits in themselves as well as the human traits in the animals they read (about), so as to reconsider what may already be deeply entrenched but not ineradicable notions of human exceptionalism. My overall goal, as is Donovan's ([14], p. 214), is to encourage scholars to reconceive the status of animals in literature so as to change their ontological place in the world. This can be done by recalibrating ethical decision-making to treat animals not as Immanuel Kant suggested in his Lecture on Ethics (1779), 
"merely as means to an end" ([41], p. 56), and not as "helpers" or "property of man," views as old as Genesis which are frequently claimed as "natural rights" but are, in Singer's words, "ideological camouflages for [our] self-serving practices" ([1], p. 186)—but as sentient beings worthy of love, respect, and equal protection before the law.

Acknowledgments: I wish to thank Joela Jacobs, the Guest Editor of this special issue of Humanities, for her encouragement and the journal's editorial staff for their assistance. I wish also to thank Peter Singer, Kari Weil, and Josephine Donovan whose work on animals continues to inspire my research and teaching.

Conflicts of Interest: The author declares no conflicts of interest.

\section{References}

1. Peter Singer. Animal Liberation. New York: Ecco (HarperCollins), 2002.

2. Theodore Ziolkowski. "Talking Dogs: The Caninization of Literature." In Varieties of Literary Thematics. Princeton: Princeton University Press, 1983, pp. 86-122.

3. Kari Weil. "A Report on the Animal Turn." Differences: A Journal of Feminist Cultural Studies 21 (2010): 1-23. Available online: http://differences.dukejournals.org/content/21/2/1.full.pdf+html (accessed on 11 November 2016). [CrossRef]

4. Brett A. Berliner. "Gods We Were: Rejuvenation as Social Metaphor in Interwar Pulp Fiction in Europe and the United States." Interdisciplinary Humanities 30 (2013): 101-12.

5. Ellendea Proffer. Bulgakov: Life and Work. Ann Arbor: Ardis, 1984.

6. Viktor Shklovsky. "Art as Technique." In Modern Criticism and Theory: A Reader. Edited by David Lodge. Translated by Lee T. Lemon and Marion J. Reis. New York: Longman, 1988, pp. 16-30. Available online: https: //paradise.caltech.edu/ist4/lectures/Viktor_Sklovski_Art_as_Technique.pdf (accessed on 11 November 2016).

7. Susanne Fusso. "Failures of Transformation in Sobač'e Serdce." The Slavic and East European Journal 33 (1989): 386-99. [CrossRef]

8. Ronald D. LeBlanc. "No More Horsing Around: Sex, Love, and Motherhood in Tolstoi's Kholstomer." Slavic Review 70 (2011): 545-68. [CrossRef]

9. Andrea Rossing McDowell. "Lev Tolstoy and the Freedom to Choose One's Own Path." Journal for Critical Animal Studies V (2007): 1-18. Available online: http://www.animalliberationfront.com/Philosophy/ mcdowell-tolstoy.pdf (accessed on 11 November 2016).

10. Josephine Donovan. "Tolstoy's Animals." Society and Animals 17 (2009): 38-52. Available online: http://www.animalsandsociety.org/wp-content/uploads/2015/04/Tolstoys_Animals.pdf (accessed on 11 November 2016). [CrossRef]

11. Constantine Sandis. "Understanding the Lion for Real." In Knowledge, Language and Mind: Wittgenstein's Thought in Progress. Edited by Antonio Marques and Nuno Venturinha. Berlin and Boston: De Gruyter, 2012, pp. 138-61. Available online: https://www.academia.edu/1496859/Understanding_the_Lion_For_Real (accessed on 11 November 2016).

12. William Nelles. "Beyond the Bird's Eye: Animal Focalization." Narrative 9 (2001): 188.

13. Gerard Genette. Narrative Discourse: An Essay in Method. Translated by Jane E. Lewin. Foreworded by Jonathan Culler. Ithaca and New York: Cornell University Press, 1980.

14. Josephine Donovan. "Aestheticizing Animal Cruelty." College Literature 38 (2011): 202-17. [CrossRef]

15. James Berger. "Trauma and Literary Theory." Contemporary Literature 38 (1997): 569-82. [CrossRef]

16. Francis C. Colpaert, Philippe De Witte, Allan N. Maroli, Frans Awouters, Carlos J. E. Niemegeers, and Paul A. J. Janssen. "Self-Administration of the Analgesic Suprofen in Arthritic Rats: Evidence of Microbacterium butyricum-Induced Arthritis as an Experimental Model of Chronic Pain." Life Sciences 27 (1980): 921-28. [CrossRef]

17. Jonathan Balcombe. What a Fish Knows: The Inner Lives of Our Underwater Cousins. New York: Farrar, Straus and Giroux, 2016.

18. Cathy Caruth. Unclaimed Experience: Trauma, Narrative and History. Baltimore and London: Johns Hopkins University Press, 1996.

19. Temple Grandin, and Catherine Johnson. Animals in Translation: Using the Mysteries of Autism to Decode Animal Behavior. Orlando: Harvest, 2006. 
20. Leo Tolstoy. Master and Man and Other Stories. Translated by Ronald Wilks, and Paul Foote. Introduced by Hugh McLean. London and New York: Penguin Classics, 2005.

21. Lev N. Tolstoi. Sobranie Sochinenii v Dvenadtsati Tomah, t. 10. Moskva: Gos. Iz-vo Hudozhestvennoi Literatury, 1958.

22. Karen Ryan-Hayes. "Iskander and Tolstoj: The Parodical Implications of the Beast Narrator." Slavic and East European Journal 32 (1988): 225-36. [CrossRef]

23. Mikhail Bulgakov. The Heart of a Dog. Translated by Michael Glenny, with an introduction by Andrey Kurkov. New York: Melville House, 2013.

24. Eric Laursen. “Bad Words Are Not Allowed! Language and Transformation in Mikhail Bulgakov's 'Heart of a Dog'." The Slavic and East European Journal 51 (2007): 491-513. [CrossRef]

25. Ronald D. LeBlanc. "Feeding a Poor Dog a Bone: The Quest for Nourishment in Bulgakov's Sobach'e Serdtse." The Russian Review 52 (1993): 58-78. [CrossRef]

26. Diana L. Burgin. "Bulgakov's Early Tragedy of the Scientist-Creator: An Interpretation of The Heart of a Dog." The Slavic and East European Journal 22 (1978): 494-508. [CrossRef]

27. Frans de Waal. Our Inner Ape: A Leading Primatologist Explains Why We Are Who We Are. New York: Riverhead Books/Penguin, 2005.

28. Helena Goscilo. "Point of View in Bulgakov's Heart of a Dog." Russian Literature Triquarterly 15 (1978): $281-91$.

29. Yvonne Howell. "Eugenics, Rejuvenation, and Bulgakov's Journey into the Heart of Dogness." Slavic Review 65 (2006): 544-62. [CrossRef]

30. Mikhail Bulgakov. Belaia gvardiia. Master i Margarita. Povesti. Rasskazy. Moskva: OLMA Press, 2003.

31. Kari Weil. “Thinking and Unthinking Animal Death.” In Thinking Animals. New York: Columbia University Press, 2012, pp. 116-27.

32. Michael Sprinker. "Gerard Manley Hopkins on the Origin of Language." Journal of the History of Ideas 41 (1980): 113-28. [CrossRef]

33. Alexandra Horowitz. Inside of a Dog: What Dogs See, Smell, and Know. New York: Scribner, 2009.

34. Hugh Bredin. “Onomatopoeia as a Figure and a Linguistic Principle." New Literary History 27 (1996): 555-69. [CrossRef]

35. Benjamin E. Stevens. "Symbolic Language and Indexical Cries: A Semiotic Reading of Lucretius 5.1028-90." The American Journal of Philology 129 (2008): 529-57. [CrossRef]

36. Donna Haraway. Simians, Cyborgs, and Women. London: Free Association Books, 1991.

37. Frans de Waal. Are We Smart Enough to Know How Smart Animals Are? New York and London: Norton, 2016.

38. Charles Foster. Being a Beast: Adventures across the Species Divide. New York: Metropolitan Books, 2016.

39. David Comer Kidd, and Emanuele Castano. "Reading Literary Fiction Improves Theory of Mind." Science 342 (2013): 377-80. [CrossRef] [PubMed]

40. John Maxwell Coetzee. Elizabeth Costello. New York, Toronto, and London: Penguin, 2003.

41. Ian Robertson. Animals, Welfare and the Law: Fundamental Principles for Critical Assessment. New York: Routledge, 2015.

(C) 2016 by the author; licensee MDPI, Basel, Switzerland. This article is an open access article distributed under the terms and conditions of the Creative Commons Attribution (CC-BY) license (http://creativecommons.org/licenses/by/4.0/). 